\title{
Mapping Australian Music. Review Essay
}

\section{Transforming Cultures eJournal, \\ Vol. 4 No 1 April 2009 \\ http://epress.lib.uts.edu.au/journals/TfC}

\section{Tony Mitchell}

\section{Review Essay}

Jazz: The Australian Accent, 2009, John Shand. Sydney, UNSW Press. ISBN 978-1921410-14-7, pp. 228.

Experimental Music: Audio Explorations in Australia, 2009, (ed.) Gail Priest. UNSW Press. ISBN 978-1-921410-07-9, pp. 237.

New Classical Music: Composing Australia, 2009, Gordon Kerry. Sydney, UNSW Press. ISBN 978-0-8684098-32, pp. 224.

This triptych of books from UNSW Press on contemporary Australian music, all of them complete with rather tenuously attached CD samplers in front or back cover flaps (library cataloguers beware, but this makes the asking price of $\$ 34.95$ more appealing) undoubtedly represents a major contribution to the rather sparse existing collection of books on the subject. Uniformly designed by Josephine Pajor-Markus with gold embossed titles on rather blandly anonymous covers representing saxophone keys in red, a blow-up of Dave Brown's guitar preparations in brown, and the outer curve of a violin and titles in blue over a gold background, they are clearly conceived as a set, despite their differences in scope, focus and conception. They range from the Sydney Morning Herald jazz reviewer, an edited collection of essays by a sound artist, curator and writer for Real Time covering most states by practitioners of experimental and improvised music, some of whom are also academics, to a survey of contemporary Australian "classical music" by a prominent composer. Inevitably, lacunae and omissions and contentious statements are to be found in all of them, but the fact that they exist, and all contain exhaustive indexes for easy reference, is an undeniable plus. There is also some overlap, with versatile improvising pianist Chris Abrahams of international cult group the Necks, for example, being profiled in both the Shand and the Priest volumes, along with some of his cohorts, although there could have been considerably more, given that a number of Australian 'jazz' musicians are 
also substantial figures in experimental music. By calling his volume by the conservative term 'classical music, rather than the more inclusive 'art music', Kerry basically avoids this eventuality, and one looks in vain for coverage of experimental composers such as Ron Nagorka and David Chesworth in his volume, even if they both crop up in Experimental Music. Inevitably the three volumes will find their separate constituencies and possibly generate a few polemical discussions in the process.

Toward the end of 2008 I dropped into the Basement on a week night in Sydney to catch an ironically rare double bill of performances by Australian jazz groups the Phil Slater Quartet and the Alister Spence Trio - ironic given that the Basement has such a long historical association with Australian jazz, but so little of it happens there these days. There was a fairly modest crowd, which included Shand in his professional capacity - all of the musicians bar Spence - surprisingly - are at least mentioned in this book - and what struck me most was the brilliance and vibrancy of the music, some of which I had previously heard on $\mathrm{CD}$, but which live elicited a strong physical response. None of the other people in the audience seemed to be getting these vibrations, however, and seemed to gaze on the performers like 'stunned mullets' - as the ubiquitous bass player for both groups (and the Necks, along with numerous other groups), Lloyd Swanton, commented during the interval. It was as if they were attending a concert of 'classical music', which may indicate an overly-reverential response to Australian jazz by the chosen few. This interpretation of the situation is bemoaned by Sydney Improvised Music Association (SIMA) founder Peter Rechniewski in his 2007 Currency Platform Paper The Permanent Underground: Australian Contemporary Jazz in the New Millenium, which in my view overdramatises the institutional neglect for Australian jazz and misappropriates the term 'underground' in presenting a 'modest proposal' for funding more local jazz. This will presumably come at the expense of what Rechniewski repeatedly refers to as 'rock/pop', a meaningless category which apparently covers any kind of music that is not rigidly contained within art/classical or jazz parameters (despite the fact that a number of local jazz musicians, Abrahams included, regularly participate in rock and pop music projects). One of Rechniewski's prognoses is a grotesque 'jazz and new music' series involving Ten Part Invention, Chris Abrahams, Scott Tinkler, the John Butler Trio, and Tim Friedman of the Whitlams - a ridiculously watered-down attempt to combine freeform jazz and mainstream pop in the 
misguided kind of crossover that gives all involved a bad rap. Surely 'jazz' has always been a bastard form, cannibalising other genres of music, and forging paths of improvisation, ingenuity and surprise which break the boundaries of music genres.

Shand does not proselytise, apart from the odd hyperbolic suggestion that some of the musicians he profiles are among the best in the world (Abrahams, with some degree of justification, perhaps, but James Muller "possibly the most exciting jazz guitarist alive" (p.195)? With an album entitled Kapow! Hardly.) And his selection is determinedly biased and partial - his book is not a history or an overview, but profiles of seventeen of his favourite musicians, six of whom happen to be drummers (Shand is himself a sometime drummer), and most of whom happen to be based (or were based) in Sydney. Apart from the profiles, there is an introduction on Australian jazz's 'splendid isolation', briefly contextualising it internationally, a (too) short chapter on improvisation, a single page on the 'Kiwi invasion' - a topic which could easily fill a whole book - another page-long gripe decrying audience members who clap after solos (shades of classical-style reverence here), four pages on 'missing women' which this book contributes to substantially - more on this later - a two page coda on 'future stars' and a ten page afterword about the dissemination of Australian jazz which concludes, unlike Rechniewski, that although "the routine standard of Australian creative jazz is much higher than the routine standard of many local art forms" (p.200) it is not a question of more media exposure and funding, since "[t]he audience for most post-bebop jazz is limited by the music's own complexities and intricacies, just as the audience for most classical music of the last 100 years is limited' (p.199). International exposure via the internet is one solution to the small audiences, although live performance is still fundamental - as I write, the Necks are involved in their first tour of the USA and Canada.

Shand is a lively, perceptive reviewer of jazz, and is capable of taking you right into the process of the music's evolution with a highly engaging sense of immediacy. His 'cannibalising' of previous writing here is thus forgivable, although he does reproduce a pratfall when he reproduces his description of brilliant drummer Simon Barker's "predilection for sweeping the pulse under a carpet of astutely punctuated abstraction" (p.171) - oops! Nonetheless Barker, who plays with Slater's quartet and has been 
influenced by Korean music, is truly an astounding drummer, and was a logical choice, along with Swanton, to play with US improvising pianist Marilyn Crispell when she toured Australia in 2008. Shand does him justice, as with the other musicians he profiles, drawing on quotes from extensive interviews about musical development and influences, along with astute insights into philosophies, techniques and learned experiences. Some of Shand's 'senior' choices are obvious ones: NZ-born pianist Mike Nock and saxophonist Mark Simmons, drummers Phil Treloar, John Pochée and Allan Browne and saxophonists Bernie McGann and Scott Tinkler, while amongst the younger generation only Melbourne-based sax player Julien Wilson and his band of guitarist Stephen Magnusson and accordionist Stephen Grant were previously unfamiliar to me, and I for one am most grateful for their inclusion. Tracks by all of the above as well as those previously mentioned are included on the $\mathrm{CD}$, including pianist Matt McMahon, a member of Slater's quartet as well as fronting his own trio among other groups.

There are of course many omissions, but the most drastic are those of women, compounded with a lack of referencing of previous writing on Australian jazz. The brief section on improvisation, although excellent in managing to convey an interior perspective, could have been nourished not only by reference to the late British guitarist Derek Bailey's book on the subject, but by the groundbreaking historical work Playing Ad Lib by Melbourne writer John Whiteoak (1999). Improvising pianist and academic Roger Dean's 2006 volume Sounds from the Corner: Australian Contemporary Jazz on CD, despite being rather dry, offers an invaluable documentation of and commentary on 250 CDs of Australian jazz (and some experimental music as well) released between 1973 and 2005; including a significant number involving women. In Shand's book, saxophonists Sandy Evans and Fiona Burnett and pianists Judy Bailey and Andrea Keller get brief mentions and there is acknowledgement of the important influence of the late Jann Rutherford, as well as a list of several other names, but no one gets the special attention of Shand's top squad of 17 males. Without doing a pc head-count, it is clear that Dean's book in contrast profiles work by a much more substantial and equitable number of women musicians.

One further basic question remains: what is distinctively 'Australian' about Australian jazz? Shand claims with some justification that 'no pattern emerges in quantifiable sonic 
terms' (p.1), and Swanton's claim that he is part of 'a little eddy off to the side of the mainstream, where all these amazing things can develop, informed by the rest of the world, but more or less unmolested by it' (p.11) is as good a description as any. One thing that emerges consistently in Shand's profiles is an epiphany usually experienced in New York, about the futility of attempting to emulate US models; in one or two cases there are even accounts of enduring the snobbery of African-American musicians bound to Wynton Marsalis's reactionary notion of a 'jazz tradition'. Influences come as much from Europe and Asia and one another as anywhere else, and one intriguing factor is that certain local musicians play their instruments very unconventionally: Bernie McGann's embouchure is technically 'wrong', with more of the mouthpiece placed inside his mouth than is usually acceptable; John Pochée plays a right-handed drum kit left-handed, and one of the major factors contributing to Tony Buck's extraordinary drumming style is that he likewise plays a right-handed kit left-handed. These idiosyncrasies would probably have been erased in a conventional musical education; Mike Nock, who has taught at the Sydney Conservatorium for many years after 'making it' in New York, and has played with almost every nonpianist profiled in the book, has always managed to 'personalise' the jazz standards he plays. Abrahams has likened the spaced-out minimalism of the Necks' music to driving through the Australian outback and arriving at a new place only to discover that everything that previously looked the same has suddenly changed. Which is as good an indicator of an Australian jazz 'accent' as one can get.

Before moving to Sydney from Italy in 1984 I caught a performance by legendary Sydney exponents of industrial music - a term coined by British anarcho-freaks Throbbing Grisle in 1976 - SPK (aka Sozialistiches Patienten Kollektiv, SeppuKu, Sliced Penis Klinik and various other soubriquets) at the Venue in London. The band had reputedly eaten raw sheeps' brains on stage (a relatively common occurrence in avant-garde rock at the time) and even once set an audience member alight with a flame thrower (they then proceeded to jump on him and snuff him out, so to speak), and were part of a European metal-noise triad along with Einstürzende Neubaten and Test Department who were exploring live performances and recordings with power tools, ultra-sound, metal objects excavated from dumps and generally thrilling the cognoscenti with Nazi, Russian constructivist, postindustrial wasteland and horror-gore imagery. On the night in question, after a grinding, 
brain-splitting set featuring exotic female vocalist Sinan and various metallic percussive objects, as well as bursts of fire, group leader Graeme Revell (also known as 'Oblivon' (sic)) began swinging a heavy duty chain perilously close to the audience, and the gig was promptly shut down by security staff wielding fire extinguishers and closing the stage curtain. It was all very exciting, and one of the support groups on the night - which we missed - was Sonic Youth, but that's another story. Later I heard stories passed around Sydney in hushed tones of the group's legendary performance at the Brickworks in Sydney Park, St. Peters in March 1982 (a venue recently used illegally for the battery-powered alternative Tropfest, Squatfest, set up 'because TropFest sux corporate cocks'). Experimental Music: Audio Explorations in Australia features a murky photograph of this SPK Brickworks gig (p.49) with three group members, two of them former psychiatric nurses, swathed in Western outlaw (or revolutionary underground) scarves covering their faces, with Ni/H/il (aka Stephen 'Neil' Hill) also sporting a trendy (unreversed) baseball cap. (A barely visible fragment of a track from this concert entitled 'Agony of the Plasma', with repeated screaming, a siren-like dirge, and Revell banging something with a piece of metal, is retrievable on YouTube, along with a number of the group's videos, including their 1982 magnum opus Despair, re-released in a deluxe version in 2007, which appears to feature some sheep brain eating. Watching them is rather like sampling a snuff movie, although there are also some genuinely lyrical moments, like the sci-fi operatic 'In Flagrante Delictu'.) SPK subsequently mutated into a synth-pop band, releasing a single, 'Metal Dance', promoting it on the ghastly Jools Holland's BBC music show Later, and then consigning an album, Machine Age Voodoo, to WEA in 1984, before embarking on a reportedly disastrous tour of Australia in 1995. The album features a picture of Sinan clad in an orientalist turban, and a solemn bare-chested Hitler youth-style Revell dressed like a caveman in what looks like scraps of garbage bags. Revell went on to become a Hollywood film composer, scoring mainstream semi-cult films like Dead Calm, The Crow, The Basketball Diaries and Pitch Black.

SPK get two guernseys in Experimental Music, with Ian Andrews and John Blades in a chapter entitled "The Lost Decade" describing them as "charting the absolute extreme marginal terrain of the social" through "extremely loud walls of noise ... deep lowfrequency rumbles and infra-sound, unsettling the listener" and succeeding in producing "a 
genuinely evil sound" (p.50). They also claim that SPK, along with Melburnians Whirlywirld (featuring Ollie Olson, also later to mutate into techno-dance pop and film music) became "the blueprint" for industrial music in the US, the UK, Europe and Japan in the 1980 s - no mean achievement. In the following chapter, aptly entitled "Cultural Terrorism and anti-Music", Cat Hope, aka Snagglepus, a "low frequency sound artist" and music co-ordinator at WAAPA, reports that SPK were William Burroughs' favourite band, and claims "they are (sic) the only Australian band to maintain their reputation as important figures in the international evolution of the Noise genre" (p. 60). Neither chapter mentions the group's scandalous transmogrification into synth-pop, or that the name SPK has recently been trademarked by another noise music merchant called Mario de Vega - shades of what ironically happened to British sampledelic pranksters the KLF, whose name ended up as a disco franchise. One of the original SPK cohorts, calling himself Tone Generator, recorded an obituary for the group on YouTube in a Sydney graveyard in 2007. They have been an enduring influence on Jamie Leonarder's Mu-Mesons franchise, which occasionally performs music as Mu-Mesons Antagonists with mental patients. But Leonarder, an active participant in the Sydney experimental music scene since the 1980s, is reduced to a footnote in "The Lost Decade". Given the numerous repetitions and overlaps involving other musicians mentioned throughout the book - surely an argument for more diligent editing - this seems like a serious oversight. In Bob Blunt's Blunt: A Biased History of Australian Rock, Leonarder reveals that he toured Australia in 1985 with a disintegrating version of SPK, post "Metal Dance", who were "probably one of the main reasons why the Mu-Mesons existed ... they were really into the whole art brut movement, supporting the isolated and the marginalised" (Blunt 2001:109, 111). ${ }^{1}$ Another problem that emerges in a book of this nature, is that since there is so much to cover, despite the repetitions, there is apparently no room for any critical analysis, a lack acknowledged by Priest in her brief preface, modestly entitled 'Starting Somewhere'.

In a review of Experimental Music for British avant-garde style music bible The Wire, Nick Cain (2009) suggests, rather harshly perhaps, that the book and accompanying CD "fail to communicate any real insight into what might make Australian experimental music inherently or uniquely either Australian or experimental", claiming there is an over-reliance

\footnotetext{
${ }^{1}$ Bob Blunt (2001) Blunt: A Biased History of Australian Rock, Melbourne: Prowling Tiger Press.
} 
on "census-taking, mechanically documenting", and an "absence of analysis of the social and political contexts" of the music covered. He laments the reduction of the Necks to a six-line paragraph - obviously not having recourse to their extensive coverage in Shand's book - and, with some justification, the devotion of a whole chapter to the dubious achievements of the electronic dance music collective Clan Analogue, who arguably belong in another book about Australian electronic music (Cain 2009:73).

Map-making is a difficult procedure when dealing with music that Priest describes as "what happens when you go off the map" (p. 2), and she wisely posits the book as an "incomplete beginning" for further research, stating that the chapters "foreground people and activities in an attempt to document these practices, rather than to offer theoretical analysis" (p. 7). Nonetheless, despite the overall blandness and descriptiveness of the writing, given such a potentially explosive subject, there are a few theoretical references that rise to the surface, as one would expect from academic writers. Julian Knowles draws on popular music theorists Will Straw and Andy Bennett in 'setting the scene' with a rather sketchy overview of Australian experimental music since the mid-1990s. Andrews and Blades, after decrying the 'glaring absence' of any discussion of experimental and industrial music in the 1970s and 1980s, then proceed to reference two of the standard texts on these decades, Simon Reynolds' (2005) Rip It Up and Start Again on UK and US scenes, and Clinton Walker's (1982) Inner City Sound on the Sydney and Melbourne scenes. In defining "noise music" as "music made by what other musicians would call the detritus of the music process" (p. 57) despite the numerous writings on the subject by Hegarty, Bruce Russell and others, Hope pretty much confines herself to a narrative of local noise music producers and musicians, although her attention to the fences and wires projects of Jon Rose and Alan Lamb is welcome. Shannon O'Neill tackles sampling and the copyright question, a minefield of a subject much discussed and debated in popular music studies, covering important Australian 'sampledelic' figures such as Severed Heads, Rik Rue, the Loop Orchestra, Warren Burt and Newcastle's Bloody Fist label, and even briefly mentioning the experimental hip hop of Curse of Dialect and New Pollutants. He does reference important precedents such as copyright terrorists Negativland and John Oswald's 'Plunderphonics' (but not the KLF - aka Kopyright Liberation Front), and refers to the now abandoned mash-ups of Dscico in his numerous guises, suggesting that mash-ups, Creative Commons 
and increased internet distribution spell an erosion of copyright obstacles for sampling and remixing musicians - a rather simplistic conclusion that doesn't really involve itself deeply enough in the ongoing debates. Simon Frith and Lee Marshall's edited volume Music and Copyright (2004) might have been a good place to start. But when Priest and Seb Chan claim 'the music of the future will be electronic' (p.102), I really part company with some of the assumptions made here - thankfully we have defiantly acoustic groups like the Necks to prove this assertion wrong. And it is unfortunate there is no space either here or in Shand's book for Triosk, a Sydney-based electronic-jazz minimalist group featuring pianist Adrian Klumpes, who has also recorded solo, who have a major international reputation and have released albums on the UK leaf label.

Alistair Riddell provides a useful chapter on computer music, which foregrounds the active roles that University music departments such as Latrobe, Melbourne and Western Sydney have played in its development in Australia, while Jim Denley focuses on a personalised view of 'improv' - a rather twee term not always welcomed by some improvising musicians - drawing on his experiences with Jon Rose, Rik Rue and the Machine for Making Sense as well as Ross Bolleter, whose music on ruined pianos in Western Australia surely makes him one of the most distinctive musicians in this company, and one whose work is directly embodied in place and landscape - where "the piano has been prepared by the desert" (p.143). Other major figures in the broad experimental field such as Oren Ambarchi, Lucas Abela, Antony Pateras and the Splinter Orchestra are also covered, although repetition is becoming a problem by this stage. Ultimo pub the Evil Star, where I once witnessed Ambarchi in the 1980s with his avant-metal group Phlegm, parodying Queen and surrounded by a bevy of Sydney con-type women in black underwear stage diving from a non-existent stage into a very sparse audience, is also given its reverential fifteen minutes.

Probably the strongest and most consistently argued chapter in Experimental Music is Virginia Madsen's account of the role of ABC radio, and to a lesser extent, 2MBSFM in Sydney, in its rather perfunctory fostering and producing of local radiophonic experiments in sound and music. Speaking from the perspective of an involved practitioner since the 1980s, she provides a brief history of the development of audio experiments on the ABC 
since the 1960s - when David Ahern, returning from studies with Stockhausen in Cologne, proposed an electronic music studio to a general response of disdain - through programs such as Surface Tension and The Listening Room in the 1980s and 1990s and onto the more promising terrains of digital audio broadcast in the $21^{\text {st }}$ century. Madsen is also one of the few authors to present Australian work in a global context, with particular reference to radiophonic experiments in France and Germany. Kaye Mortley is a key figure here, but the brief extract from her work included on the CD doesn't really do her extensive work justice. Sean Bridgeman offers a descriptive catalogue of instrument makers, which mainly consists of an array of blokes in sheds tinkering with debris, with Rose and Bolleter inevitably cropping up again as figures who take their work out of the shed and into the desert, along with Jodi Rose, who specialises in rather megalomaniacally creating music from the giant Aeolian harps provided by bridge cables. There is no attempt here to link these activities to notions of Australian maverick individualism and inventiveness - surely a missed opportunity.

Priest rounds things off with a survey of audiovisual and mixed media work, where some of the usual suspects inevitably crop up yet again - such as Robin Fox, Philip Brophy and Nigel Helyer, to mention some names not previously mentioned in this review. Priest concludes that 'it is difficult and perhaps futile to try and identify an inherently Australian character to these practices' (p.213), a caveat that presumably stands for the entire book. But is it so difficult? Surely the work of Rose, Lamb, Bolleter, Rue and numerous others who use exterior desert locations or water along other particularised settings and contexts for their work have a distinctively Australian identity? Many of these musicians have a stronger international reputation than they do within Australia, and a decidedly transnational orientation as a result, but how are they perceived from outside Australia? What associations does 'Australian experimental music' produce in, say, Paris, where Kaye Mortley has worked for many years, or Berlin, where Tony Buck, Clayton Thomas and Clare Cooper are now based, or Tokyo or Beijing? Going back to SPK, could they have emerged from any other environment than Sydney or Melbourne in the late 1970s? SPK's similarities to Einstürzende Neubaten and Test Department suggest otherwise, but Hope claims their music differed from other international noise music groups on the 1980s "in the way it combined incidental noise 'faults' (hissing, grating, unplugging) with machine 
pulsations and jarring bursts of noise" (p. 60). They were also an important influence on subsequent local Noise groups such as Mesh and transplanted Kiwis Fetus Productions, as well as the Mu-Mesons. Andrews and Blades suggest that their music primarily "emerged out of the extremely abrasive guitar and electronic noise post-punk typified by local groups Voigt/465 and Primitive Calculators" (p. 50) who were part of Melbourne's "North Fitzroy Beat" produced by the "little band" movement of ad hoc performance groups. In 1979 Voigt/465, according to Clinton Walker in Inner City Sounds, "introduced a much-needed progressive element to Sydney, where mindless headbanging refused to die" (Walker 1982:55) - elsewhere, Walker features them in a "rare photo" taken with SPK's Ne/H/il (p. 62). This suggests a local cross-fertilisation of musical influences that engages with developments in the post-1976 Do-It-Yourself Australian post-punk music of disenchanted art students, which Walker has described as "a distinct movement which for perhaps the first time, has moved closer towards an Australian rock of its own invention and identity" (p. 5). Which is at least starting somewhere.

I'm listening to Michael Kieren Harvey's 2007 recording The Piano Music of Mike Nock. It sounds stiff, wooden and formal to me, with the dryness and austerity of a number of classical piano works. Not as flamboyant as Rachmaninov, or as shimmering as Debussy or Ravel, but cold and dull. And nothing like the way that Nock plays his own work, say, on a recording such as his 1982 ECM disc Ondas, where his piano really sings and is full of curved edges and lyrical improvised syncopations. Harvey's versions sound placeless, severe and far too classically structured. There's a photo of Harvey in Gordon Kerry's New Classical Music: Composing Australia (p.162), with his eyes closed, seemingly in a trance, and he is invoked in a brief section on performers of Australian 'classical' music as an important interpreter of the music of Carl Vine. Vine is one of the more conventional contemporary Australian composers, having composed seven symphonies and a number of string quartets and piano sonatas, justifying the term "classical" in Kerry's title, rather than the more inclusive 'art music'. Kerry notes the influence of US composer Elliott Carter's 'metrical modulation' on Vine's work, and the importance of his collaborations with Graham Murphy and the Sydney Dance Company, as well as how in 1986 "he foreswore dogmatic modernism and developed a new style based on a rethinking of traditional melody and diatonic harmony" (p. 150). Perhaps that explains why Vine's music doesn't do much 
for me - it sounds conventional, familiar and passé. And I can't hear anything "Australian" in it - it could almost have been composed more than half a century ago.

A number of the other composers dealt with in Kerry's book are of a similar ilk to Vine indeed he points out on page 2: "This book is about notated western art music for acoustic instruments" - which rules out any electroacoustic compositions for a start. He then offers further limitations: "I am not a musicologist and this is not a work of academic scholarship; nor does it have any pretensions to being encyclopaedic" (p. 3). So we are to assume, as in the case of Shand's book, this is a book about a selection of composers Kerry happens to like - fair enough, as far as it goes. Kerry saves his other clanger for his conclusion:

I have deliberately not written about the younger generation, though it includes some highly talented people. And I have avoided talking about the several younger composers now living and working overseas (p. 206).

Which narrows things down even further, although Kerry's bibliography of earlier writings on Australian music is far more substantial than Shand's or Priest's, and he provides a useful outline of the availability of the work he analyses here on CD, and the major works by the composers he covers. He also modestly refrains from mentioning his own work Kerry is a Melbourne-based composer and journalist who studied with Barry Conyngham and was recently composer-in-residence at the Australian National Academy of Music which Arts Minister Peter Garrett threatened to close down in October 2008. Kerry claims that he has been called "misogynist", "the devil in Australian music", and "a musicological monarchist" by some of the people referred to in this book, although it is hard to see why. Clearly there is a backdrop of vicious polemic here which is only alluded to briefly in Kerry's reference to the "pretty ugly" debate in the magazine Sounds Australian in 1990 between a group supporting "an uncompromising modern aesthetic in which one could faintly discern the remains of the avant-garde's political program" (p. 95) and a group representing "the resurgence of tonality among younger composers in Australia" (p. 97) around 1990. The latter process, he argues, had begun in the 1970s when "a number of significant composers experience[d] a damascene road conversion from modernism to a renewed interest in diatonic music" (p. 96). But Kerry is rather vague about the debate, which he never successfully contextualises, apart from making the occasional disparaging 
references to serialism and composers such as Boulez and Stockhausen. To an outsider such as myself, it seems that a political agenda is being played out here, but nonetheless there is still much that is of considerable interest. At one point Kerry invokes a couple of "household names" from the mid-20th century, at least "to households where members do AMEB (Australian Music Education Board) exams, at least" (p. 12) which rules me out, for one, and suggests the target audience may be something of an elite. To my layperson's eye and ear, despite Kerry's claims of not being a musicologist, far too much of this book reads like the kind of densely descriptive accounts of musical compositions, complete with notated illustrations, one gets in a concert program or on a classical CD liner, most of which I, and the general reader I suspect, frankly don't understand, and which conveys very little of the affect or meaning, not to mention the 'Australianness' of the music.

In his chapter on Conyngham in Fiona Richard's far more heterogeneous edited volume The Soundscapes of Australia: Music, Place and Spirituality, 8 which situates both art music and Aboriginal music in relation to place, and which I have reviewed elsewhere, Kerry succeeds in locating Coyngham in an Australia of what the composer has called the

intimidating grandeur of its landforms, the subtlety of its changes. The often slow moving, almost monolithic, underlying harmonic tensions ... of Aboriginal music (in Richards 2007:247).

He does this through the use of "large scale fields dominated by a restricted number of intervals" (Ibid. p. 249), while elsewhere, such as in Conyngham's 1999 piece Fix, a monodrama about Brett Whitely, he evokes Sydney harbour as a genius loci, and other works invoke the harsh landscapes of convict Australia, and the experiments in powered flight of Lawrence Hargrave (1850-1915) on the beach of Point Piper. Kerry concludes:

the sense of place in this composer's work refines the individual's image of his or her own role and significance in the larger environment. City or landscape can be the backdrop for a traumatic, but self defining experience (Ibid. p. 263).

More of this kind of observations in New Classical Music: Composing Australia would have been welcome, especially given the geographical implications of the subtitle, but there are few, if any, to be found. Most sections do not even have concluding remarks, but 
simply follow the progression of particular compositions and then stop when the music stops. Unless one happens to be listening to the work in question at the time - and I was surprised to be able to find some of the pieces analysed here in my CD collection - this is not very helpful.

The book begins promisingly with a chapter on the Australian landscape, with inevitable, but fortunately not extensive, reference to Peter Sculthorpe and his notion of irkanda, or 'lonely place' (p. 20) along with his use, like a number of other composers, of drone basses to evoke the background of the desert and birdsong to create foreground events in a "visual analogue". Three operas - Richard Meale's Voss, Moyah Henderson's Lindy and Andrew Schultz's Journey to Horseshoe Bend are then briefly discussed in terms of their use of the outback as dramatic scenarios; in the first case, landscape is "in a sense depicted by its musical absence" (p. 24) since the focus is on character psychology, although the music has echoes of John Anthill's pioneering, if highly synthetic 1946 orchestral ballet work Corroborree. Henderson conceived Lindy as a "white woman's dreaming", and uses birdsong, while Schultz employs "textbook landscape music with a drone supporting simple melodies" (p. 27). After short descriptions of the music employed in each, no conclusions or evaluations are offered.

The following chapter, "Going Native?" touches on the ethical issues of employing Aboriginal music and instruments such as the didjeridu in classical works, but makes no reference to the literature on the instrument, such as Karl Neuenfeld's important 1997 edited volume The didjeridu: from Arnhem Land to Internet, before briefly discussing Colin Bright's Earth Spirit (1989), arguably the first classical composition to use a didjeridu. Kerry argues, with some justification, that the way composers have approached Aboriginal music in the past two decades is "much less imperialist and more collegiate ... much more dialogic" (p. 34), noting the influence of didj player William Barton on a number of recent compositions by composers such as Elena Kats-Chernin and Liza Lim. He analyses Lim's Compass, "the most successful work for didjeridu and western instruments so far" (p. 35), in some detail, including reference to her intriguing use of insect clickers, noting that the work successfully integrates the changing nature of Aboriginal musical tradition with western traditions, although Lim's music also incorporates Asian musical 
traditions. She is one of the most distinctive composers covered here, and discussion of her work could have been more extensive.

"Other (Australian) Landscapes" offers the rather disingenuous observation that "few of the landscapes that figure in Australian music are actually inhabited by the people who write the music or for whom it is written" (p. 45) and looks briefly at a number of geomorphic and urban aspects of a range of works before settling back on by Sculthorpe and David Lumsdaine, a composer who uses birdsong and landscape in a more formalised way. AsianPacific influences are examined in composers such as Meale, Anne Boyd and Larry Sitsky, and Kerry invokes Edward Said's Orientalism in terms of the exoticism and "dream world" of many western musical evocations of Asia, which are like "travelogue music", similar criticisms applying to Aboriginal appropriations in some cases (p. 62). Conyngham is then discussed - a composer who broke the mould by deciding to study in Japan with Toru Takemitsu rather than going to Europe like his predecessors and contemporaries - along with Brian Howard, who with other composers, has used works by novelist Yukio Mishima as the basis of his compositions. We then shift to Europe, focusing on composers such as the eccentrics Gerard Brophy (also a Mishima fan) and Michael Smetanin, a devote of rock music, National Academy director Brett Dean and Offspring Ensemble director Damien Ricketson. Graeme Koehne's music draws on influences from elevator and lounge music (Les Baxter, John Barry, etc.), in an attempt to challenge the elitism of classical music in a more entertainment-based ethos (but surely still remains within the restrictive confines of “classical” music), while Ross Edwards's work evokes landscape, rainforest, birds, insects and frogs in a more "sacred style". Paul Stanhope offers a more personal geography, where influences come from the British pastoralism of Vaughan Williams and the more 'spiritual' side of Stravinsky. British expats Roger Smalley and Andrew Ford are discussed, with Kerry attempting to argue that their use of unashamedly British musical influences means that, unlike in the 1970s, when "traces of a British accent ... were seen as a symptom of the cultural cringe"

the conversation about "Australian" music has finished with narrow notions of nationality and it is a sign of some maturity that this [ie. UK-based] material is now available without the cultural baggage (p. 126). 
I remain sceptical about this, especially if Ford's rather fruity A reel, a fling and a ghostly galliard - included on the CD - is any indication. One of the recurrent features here is the continuing extensive use by a number of Australian composers of conventional British and European models and influences - names like Vaughan Williams, Britten, Tippett, Mahler and Richard Strauss seem to recur quite frequently. While a work such as Constantine Koukias' Days and Nights With Christ has the hallmarks of genuine innovation, drawing on the composer's Greek background, and the manic music of Elena Kats-Chernin, Gerard Brophy, Liza Lim, Mary Finsterer, Larry Sitsky, Michael Smetanin and a few others covered here invite further exploration, are we really getting the full picture? One editorial defect of the book is the frequent repetition of information, and Kerry's tendency to invoke what seem like totally inappropriate literary and musical analogies (Mozart, Emily Dickinson), along with the lack of any conclusive and evaluative overviews of the composers covered, and of their connections (or otherwise) with Australian topographies, are real limitations. Apart from an excerpt from Smetanin's Micrographia, a brief blast of Kats-Chernin's solo piano piece Tast-En and a passage of David Lumsdaine's familiar use of actual recorded birdsong, there is little on the CD that invites a second listen; at 45 and a half minutes it's a bit on the short side and another half hour of music could have been squeezed in.

Inevitably one comes away from these three books with mixed feelings; a reader who is engaged with all aspects of Australian music has a right to expect more. Shand's book is the most satisfying for me, despite its limitations, in its capacity to convey the processes of the music and the idiosyncrasies of each musician. The Priest volume seems to barely scratch the surface, and Kerry's book could have contained considerably more evaluation of the music rather than mere description. None of them engages to my satisfaction with the geopolitical aspects of Australian music, but they are nonetheless useful works of reference.

\section{Bibliography}

Cain, M. (2009) review of Experimental Music: Audio Explorations in Australia, The Wire, no. 301, March 2009, p.73.

Dean, R. (2006) Sounds from the Corner: Australian Contemporary Jazz on CD, Sydney:Australian Music Centre. 
Frith, S. \& Marshall, L. (eds.) (2004) Music and Copyright, Edinburgh University Press ( $2^{\text {nd }}$ edition).

Neuenfeldt, K. (ed.) (1997) The didjeridu: from Arnhem Land to Internet, Sydney: J. Libbey/Perfect Beat Publications.

Rechniewski, R. (2007) The Permanent Underground: Australian Contemporary Jazz in the New Millenium, Sydney: Currency Press Platform Paper.

Reynolds, S. (2005) Rip It Up and Start Again: Postpunk 1978-84, London: Faber \& Faber.

Richard, F. (2007) The Soundscapes of Australia: Music, Place and Spirituality, Aldershot: Ashgate.

Walker, C. (1982) Inner City Sound, Sydney: Wild and Woolley.

Whiteoak, J. (1999) Playing Ad Lib:Improvisatory Music in Australia 1836-1970, Sydney: Currency Press. 